\title{
Gas Chromatography-Mass Spectrometry (GC-MS) and evaluation of antioxidant and antimicrobial activities of essential oil of Campomanesia adamantium (Cambess.) O. Berg (Guavira)
}

\author{
Isabel Duarte Coutinho ${ }^{1}$, Claúdia Andréa Lima Cardoso ${ }^{1,2}$, Nilva Ré-Poppi ${ }^{1}$, Adriana Mestriner \\ Melo $^{3}$, Maria do Carmo Vieira ${ }^{4}$, Neli Kika Honda ${ }^{1}$, Roberta Gomes Coelho ${ }^{1, *}$ \\ ${ }^{1}$ Department of Chemistry, Federal University of Mato Grosso do Sul, ${ }^{2}$ Course of Chemistry, State University of Mato Grosso \\ do Sul, ${ }^{3}$ Department of Biology Science and Health, University Center of Grande Dourados, ${ }^{4}$ Department of Agronomy, \\ Federal University of Grande Dourados
}

\begin{abstract}
The essential oils from Campomanesia adamantium (Cambess.) O. Berg leaves, collected in the reproductive (flowering and fruit-bearing) and vegetative stages, were characterized by GC-MS (Gas Chromatography-Mass Spectrometry). A total of 95 compounds of the essential oils were identified. In the reproductive stage (flowering) the major constituents were monoterpenes (limonene, $\alpha$-pinene and $\beta$-pinene) while during the vegetative stage the major constituents were the sesquiterpenes (bicyclogermacrene and globulol). The essential oil of the reproductive stage shows high antimicrobial activity against Staphylococcus aureus, Pseudomonas aeruginosa and Candida albicans, and all show moderate activity against Escherichia coli. The essential oils were also evaluated for their radicalscavenging activity by DPPH. The chemogeographical variations of the oil composition from the four distinct localities studied all contained $\alpha$-pinene, $\beta$-pinene, limonene, linalool, $\beta$-caryophyllene, germacrene $\mathrm{D}$ and bicyclogermacrene, however the samples from Jardim city contained neither limonene nor linalool.
\end{abstract}

Uniterms: Campomanesia adamantium/antioxidant activity. Campomanesia adamantium/antimicrobial activity. Guavira. Essential oil/caracterization.

\begin{abstract}
Os óleos essenciais obtidos das folhas de Campomanesia adamantium foram caracterizados através da combinação de CG-EM e índice de retenção, sendo identificado um total de 95 compostos. Na floração as substâncias majoritárias foram monoterpenos (limoneno, $\alpha$-pineno e $\beta$-pineno) e durante o estágio vegetativo as substâncias majoritárias foram sesquiterpenos (biciclogermacreno e globulol). Os óleos essenciais obtidos da floração e frutificação mostraram alta atividade contra Staphylococcus aureus, Pseudomonas aeruginosa e Candida albicans e moderada contra Escherichia coli em todos os estágios. Foi avaliada a atividade antioxidante dos óleos essenciais usando o método do DPPH. O óleo essencial das 4 cidades mostrou a presença de $\alpha$-pineno, $\beta$-pineno, limoneno, linalol, $\beta$-cariofileno, germacreno D e biciclogermacreno, mas a amostra da cidade de Jardim não apresentou limoneno e linalol.
\end{abstract}

Unitermos: Campomanesia adamantium/atividade antioxidante. Campomanesia adamantium/atividade antimicrobiana. Guavira. Óleo essencial/caracterização.

\section{INTRODUCTION}

Essential oils are complex mixtures of isomers such as monoterpenes, sesquiterpenes, aromatic compounds

\footnotetext{
*Correspondence: R. G. Coelho. Departamento de Química, Universidade Federal de Mato Grosso do Sul - UFMS, Caixa Postal 549, 79070-900 - Campo Grande - MS, Brazil. E-mail: robertacoelho@yahoo.com.br
}

and aliphatic compounds (Zhao et al., 2005). Plants rich in aromatic compounds can have ecological functions, besides those that are used as alternative remedies for the treatment of many infectious diseases or the preservation of food from the toxic effects of oxidants (Tepe et al., 2004).

Quantitative and qualitative differences in the terpene compositions of some plants might be influenced by 
different phenological stages as well as environmental factors, as shown in the studies of Thymus vulgaris (Hudaib et al., 2002). For example, variations in the chemical composition at different phenological stages have been associated with the alteration of the chemical composition in antimicrobial activities, e.g., studies of the essential oils of Salvia sahendica (Salehi et al., 2007).

Nowadays, studies of the variability of compounds in plants associated with the evaluation of antioxidant and antimicrobial activities are important. The prevention of cancer and cardiovascular diseases has been associated with the ingestion of fresh fruit, vegetables or teas rich in natural antioxidants (Ramalho, Jorge, 2006). Substances with antimicrobial activities are used in the treatment of infectious diseases, as well as antifungal agents in plants that assist in the treatment of opportunistic systemic mycoses (Rahalison et al., 1994).

Campomanesia adamantium (Cambess.) O. Berg (Myrtaceae) is a small tree with edible fruit, commonly known as guavira or guabiroba. A species native to the Brazilian Cerrado bioma (Lorenzi et al., 2006), the fruit is widely used to make liqueurs, juices and sweets. There are few studies published about the chemical composition of leaves of this genus.

The essential oils of the C. guazumifolia, C. rhombea and $C$. xanthocarpa leaves are the most studied species (Limberger et al., 2001), while only the essential oil from the C. adamantium (Vallilo et al., 2004) fruit has been studied. Studies reported the isolation of three yellow pigments of the $C$. lineatifolia seeds, named champanones. Terpenes were identified in volatile extracts of pulp, peel, leaves and seeds in the same species (Bonilla et al., 2005; Osorio et al., 2006). Chemical studies of Campomanesia genus have identified quercetin, myricetin and rutin by HPLC (Schmeda-Hirschmann, 1994).

This paper describes the identification of essential oil constituents obtained at the three different phenological stages associated with the evaluation of the antioxidant and antimicrobial activities and variability of the chemical composition of four samples collected from different geographical regions.

\section{MATERIAL AND METHODS}

\section{Chemical analysis}

The solvents employed in CG-MS (Gas Chromatography-Mass Spectrometry) analysis were nanopure grade purchased from Merck (Darmstadt, Germany), whereas $n$-Alkane $\left(\mathrm{C}_{10}\right.$ to $\left.\mathrm{C}_{21}\right)$ solvents were obtained from Sigma Chemical Company (St Louis, MO, USA). The solvents employed in other analyses were of analytic grade. DPPH was purchased from the Sigma Chemical Co., USA, while quercetin was obtained from Sigma-Aldrich.

\section{Antimicrobial analysis}

The materials used for antimicrobial activity were obtained from Mueller-Hinton Agar (Oxoid ${ }^{\mathbb{}} /$ Brazil). The microorganisms (Staphylococcus aureus (ATCC 25923), Pseudomonas aeruginosa (ATCC 27853), Escherichia coli (ATCC 25922) and Candida albicans (ATCC 10231) were obtained from the American Type Culture Collection (ATCC, Reston, VA acquired from Newprov ${ }^{\circledR} /$ Brazil) and antibiotic (Nitrofurantoín, Imipenen, Tetraciclin, Fluconazol ) discs were acquired from Cecon ${ }^{\circledR} /$ Brazil, namely, nitrofurantoín $(300 \mu \mathrm{g})$ for $S$. aureus, imipenen $(10 \mu \mathrm{g})$ for P. aeruginosa, tetraciclin $(30 \mu \mathrm{g})$ for E.coli and fluconazole $(50 \mu \mathrm{g})$ for $C$. albicans.

\section{Plant Material}

The leaves of the $C$. adamantium were colleted in the state of Mato Grosso do Sul, Brazil, in the cities of Dourados (Ddos; latitude 22 ${ }^{\circ} 11^{\prime}$ '813' $S$ and longitude 054 ${ }^{\circ} 55^{\prime}$ 801 " W) during the reproductive and vegetative stages, Bela Vista (BV; latitude $22^{\circ} 06^{\prime} 35.8^{\prime \prime} \mathrm{S}$ and longitude $056^{\circ} 33^{\prime} 00.8^{\prime \prime} \mathrm{W}$ ), Bonito (BO; latitude $21^{\circ} 07^{\prime} 50.0^{\prime \prime} \mathrm{S}$ and longitude $056^{\circ} 24^{\prime} 68.0^{\prime \prime} \mathrm{W}$ ) and Jardim (Jd; latitude $21^{\circ} 25^{\prime} 02.0^{\prime} \mathrm{S}$ and longitude $056^{\circ} 13$ " 77.0 " $\mathrm{W}$ ) in 2005 during the only fruit-bearing stage. The species were identified by Marcos Sobral (UFMG) and voucher specimens 5196 (Dourados), 5198 (Bela Vista), 5197 (Bonito) and 5195 (Jardim)) have been deposited in the Mato Grosso do Sul Herbarium-HMS, Campo Grande, MS, Brazil.

\section{Essential Oil Isolation}

The oils were isolated from a $400 \mathrm{~g}$ quantity of fresh Campomanesia adamantium leaves collected during the flowering, fruit-bearing and vegetative stages and were subjected to hydrodistillation in a Clevenger-type apparatus for 4 hours. The oil percentages were expressed as w/w in relation to fresh weight of the initial material.

\section{Identification of Essential Oil Constituents}

Oil samples of C. adamantium were diluted in hexane and analyzed. Retention indices were calculated according to Zhao et al. (2005) and Isidorov et al. (1998) using a quasi-linear equation at linear temperature programmed GC operating conditions and a mixture of normal paraffin 
$\left(\mathrm{C}_{8}-\mathrm{C}_{21}\right)$ as external references. The identification of oil components was performed by comparing the spectra with those of Nist 2.0 and Saturn Libraries as well as comparison of their temperature-programmed retention indices and mass spectra with those described by Adams (1995).

\section{Apparatus}

The GC/MS system consisted of a gas chromatograph (GC 3900) equipped with an ion-trap mass spectrometer detector (Varian Saturn 2100), using a ZB-5 (5\% of phenyl-dimethylpolysiloxane), fused-silica capillary column (30 m x $0.25 \mathrm{~mm}$ i.d., $0.25 \mu \mathrm{m}$ film thickness), under the following conditions: carrier gas helium; $1 \mu \mathrm{L}$ injection volume, split at a ratio of $(1: 20)$, with initial oven temperature of $50^{\circ} \mathrm{C}$ with heating from $50^{\circ} \mathrm{C}$ to $250{ }^{\circ} \mathrm{C}$ at $3{ }^{\circ} \mathrm{C} \mathrm{min}{ }^{-1}$. The injector and ion trap detector temperatures were $240{ }^{\circ} \mathrm{C}$ and $200{ }^{\circ} \mathrm{C}$, respectively, and manifold at $70{ }^{\circ} \mathrm{C}$ with line transfer at $240{ }^{\circ} \mathrm{C}$. The MS scan parameters included an electron impact ionization voltage of $70 \mathrm{eV}$, a mass range of $40-380 \mathrm{~m} \cdot \mathrm{z}^{-1}$ and a scan interval of $0.5 \mathrm{~s}$. The antioxidant assay activity was recorded in methanol, employing a $700 \mathrm{~S}$ Femto UV Spectrophotometer at a wavelength of $517 \mathrm{~nm}$.

\section{Determination of DPPH (2,2'-diphenyl-1- picrylhydrazyl) Radical-Scavengers of Essential Oil Samples}

The free radical scavenging activity of essential oils and quercetin standard solutions were determined based on their ability to react with the stable DPPH free radical. Two milliliters of DPPH $(0.004 \%$ in methanol $)$ was added to the essential oil solution in methanol at a concentration of $2270 \mu \mathrm{g} \cdot \mathrm{mL}^{-1}$ (flowering), $2320 \mu \mathrm{g} \cdot \mathrm{mL}^{-1}$ (vegetative) and $2390 \mu \mathrm{g} \cdot \mathrm{mL}^{-1}$ (fruit-bearing). After incubation at $25^{\circ} \mathrm{C}$ for 30 minutes, the absorbance of each solution was determined at $517 \mathrm{~nm}$. The antioxidant activity (\%) of radical-scavengers was calculated as $\left(\mathrm{A}_{\mathrm{o}}-\mathrm{A}_{\mathrm{s}} / \mathrm{A}_{\mathrm{o}}\right) \mathrm{x} 100$, where $A_{s}$ and $A_{o}$ are the absorbance of the sample and control, respectively, at $517 \mathrm{~nm}$.

\section{Determination of Antimicrobial activity}

The essential oils from Campomanesia adamantium leaves, collected during the flowering, fruit-bearing and vegetative stages, were individually tested against a microorganism panel, including Staphylococcus aureus (ATCC 25923), Pseudomonas aeruginosa (ATCC 27853), Escherichia coli (ATCC 25922) and Candida albicans (ATCC 10231) in accordance with the Agar diffusion disc method
(Brasileiro et al., 2006). Briefly, the filter paper discs Whatman No. 1 (6 $\mathrm{mm}$ in diameter) were impregnated with $20 \mu \mathrm{L}$ of the essential oil ethanolic solution at 2000 $\mu \mathrm{g} . \mathrm{mL}^{-1}$. In vitro antimicrobial activity was determined using Müeller Hinton Agar and then after Agar to solidify, the plates were inoculated with a suspension of the tested microorganism $\left(0.1 \mathrm{~mL}\right.$ of $\left.1 \times 10^{8} \mathrm{UFC} / \mathrm{mL}\right)$ (turbidity based McFarland - Probac ${ }^{\circledR}$ - barium sulfate standard 0.5) and uniformly spread with a sterile swab. The discs were then applied and plates incubated at $37^{\circ} \mathrm{C}$ for 24 hours. The negative control assay was performed using only organisms and not the plant extract. The positive control used antibiotic discs $\left(\right.$ Cecon $\left.{ }^{\circledR}\right)$ for each strain assay, with the nitrofurantoín $(300 \mu \mathrm{g})$ for Staphylococcus aureus, imipenen $(10 \mu \mathrm{g})$ for Pseudomonas aeruginosa, tetraciclin $(30 \mu \mathrm{g})$ for Escherichia coli and fluconazole $(50 \mu \mathrm{g})$ for Candida albicans. The diameters of the inhibition zones were measured in millimeters. All the assays were performed in triplicate.

\section{RESULTS AND DISCUSSION}

\section{Characterization of the essential oils}

Gas chromatography-mass spectrometry (GC-MS) has been used in the separation, identification and quantification of complex mixtures, such as essential oils. As a general rule, the identification of these compounds is not precise, because the mass spectra of these compounds are very similar and determination with the standard MS library is very difficult. For this reason the retention index -IR was used as a parameter for the GC qualitative analysis of the complex mixtures of isomers.

The $C$. adamantium leaves were collected in Dourados, Mato Grosso do Sul State during the reproductive and vegetative stages of the plant and submitted to hydrodistillation. The yields were $0.32 \%$ (flowering), $0.39 \%$ (fruit-bearing) and $0.19 \%$ (vegetative). These oil samples were then analyzed by GC-MS using a temperature program with a DB-5 capillary column.

A total of 95 compounds from the different stages of C. adamantium were identified, including the presence of terpenic hydrocarbons, ether, alcohol, aldehydes, ketones, esters, phenols and epoxides. Alcohol and hydrocarbons were the predominant class. Due to the complexity of the results the components were listed in order of elution on a DB-5 column, and their retention index and percentage composition are described in Table I.

All the samples of essential oil predominantly demonstrated compounds of the cyclic series. The principal pathway of observed cyclization from the monoterpenic 
TABLE I - Volatile compounds identified in the essential oil of Campomanesia adamantium leaves at different phenological stages

\begin{tabular}{|c|c|c|c|c|c|}
\hline \multirow[t]{2}{*}{ Compounds $^{\mathrm{a}}$} & \multirow[t]{2}{*}{$\mathrm{RI}^{\mathrm{b}}$} & \multirow[t]{2}{*}{$\mathrm{RI}^{\mathrm{c}}$} & Flowering & Fruit bearing & Vegetative \\
\hline & & & \multicolumn{3}{|c|}{ Relative area (\%) } \\
\hline$\overline{\alpha \text {-thujene }}$ & 925 & 926 & 0.61 & $\operatorname{tr}$ & - \\
\hline$\alpha$-pinene & 939 & 934 & 13.23 & 7.45 & 0.07 \\
\hline$\alpha$-fenchene & 944 & 951 & 0.50 & - & 0.02 \\
\hline$\beta$-pinene & 976 & 977 & 8.99 & 6.69 & 0.06 \\
\hline myrcene & 990 & 991 & 0.88 & 0.21 & - \\
\hline mesitylene & 993 & 994 & $\operatorname{tr}$ & - & - \\
\hline$\alpha$-phellandrene & 1004 & 1005 & 0.32 & - & - \\
\hline$\delta$-3-carene & 1010 & 1011 & 0.19 & - & - \\
\hline$\alpha$-terpinene & 1016 & 1018 & 0.24 & - & - \\
\hline$o$-cymene & 1024 & 1022 & 1.49 & 0.15 & 0.09 \\
\hline limonene & 1031 & 1031 & 22.24 & 0.99 & 0.66 \\
\hline 1,8-cineole & 1030 & 1033 & 0.87 & 0.44 & - \\
\hline (Z)- $\beta$-ocimene & 1037 & 1040 & 0.03 & - & - \\
\hline (E)- $\beta$-ocimene & 1047 & 1050 & 0.28 & - & - \\
\hline$\gamma$-terpinene & 1058 & 1062 & 0.83 & 0.14 & 0.03 \\
\hline terpinolene & 1087 & 1088 & - & 0.41 & - \\
\hline$p$-mentha-2,4(8)-diene & 1088 & 1086 & 1.75 & - & 0.10 \\
\hline linalool & 1100 & 1098 & - & 4.97 & 0.53 \\
\hline$\alpha$-fenchol & 1113 & 1112 & 0.34 & $\operatorname{tr}$ & 0.27 \\
\hline cis-p-menth-2-en-1-ol & 1121 & 1121 & 0.06 & - & 0.09 \\
\hline$\alpha$-camphonelal & 1125 & 1125 & $\operatorname{tr}$ & - & 0.11 \\
\hline cis-limonene oxide & 1132 & 1134 & $\operatorname{tr}$ & - & - \\
\hline trans-sabinol & 1138 & 1140 & 0.06 & - & 0.03 \\
\hline camphor & 1143 & 1143 & - & - & 0.02 \\
\hline camphene hydrate & 1146 & 1148 & 0.11 & - & 0.02 \\
\hline isoborneol & 1155 & 1156 & 0.01 & - & 0.01 \\
\hline borneol & 1164 & 1165 & 0.45 & 0.24 & 0.37 \\
\hline 3-thujy'alcohol & 1167 & 1166 & $\operatorname{tr}$ & - & - \\
\hline terpin-4-ol & 1176 & 1177 & 0.57 & 0.26 & 0.04 \\
\hline$p$-cymen-8-ol & 1184 & 1183 & 0.09 & - & - \\
\hline (Z)-3-hexenyl butyrate & 1186 & 1186 & 0.01 & - & - \\
\hline$\alpha$-terpineol & 1190 & 1189 & 1.40 & 0.58 & 0.37 \\
\hline myrtenol & 1195 & 1194 & 0.07 & - & 0.04 \\
\hline trans-piperitol & 1206 & 1205 & $\operatorname{tr}$ & - & - \\
\hline trans-carveol & 1217 & 1217 & 0.03 & - & 0.03 \\
\hline nerol & 1227 & 1228 & 0.02 & - & - \\
\hline cis-carveol & 1229 & 1229 & 0.01 & - & - \\
\hline cumin aldehyde & 1238 & 1339 & $\operatorname{tr}$ & - & - \\
\hline carvone & 1242 & 1242 & 0.01 & - & - \\
\hline geraniol & 1254 & 1255 & 0.01 & - & 0.02 \\
\hline perilla aldehyde & 1272 & 1271 & 0.09 & - & - \\
\hline$\alpha$-terpinen-7-al & 1282 & 1282 & 0.02 & - & - \\
\hline p-cymen-7-ol & 1286 & 1287 & - & - & 0.01 \\
\hline trans-sabinyl acetate & 1290 & 1291 & $\operatorname{tr}$ & - & - \\
\hline carvacrol & 1300 & 1298 & - & - & 0.02 \\
\hline neo-dihydro carveol acetate & 1303 & 1303 & $\operatorname{tr}$ & - & - \\
\hline methyl geranate & 1323 & 1323 & 0.02 & - & - \\
\hline$\delta$-elemene & 1337 & 1339 & 0.26 & 0.29 & 0.63 \\
\hline$\alpha$-cubebene & 1349 & 1351 & 0.04 & - & 0.06 \\
\hline cyclosativene & 1371 & 1368 & 0.07 & - & 0.14 \\
\hline$\alpha$-ylangene & 1372 & 1372 & 0.05 & 0.17 & 0.10 \\
\hline$\alpha$-copaene & 1375 & 1376 & 0.37 & - & 1.40 \\
\hline isoledene & 1376 & 1373 & - & 1.57 & - \\
\hline
\end{tabular}


TABLE I- Volatile compounds identified in the essential oil of Campomanesia adamantium leaves at different phenological stages (cont.)

\begin{tabular}{|c|c|c|c|c|c|}
\hline \multirow[t]{2}{*}{ Compounds $^{\mathrm{a}}$} & \multirow[t]{2}{*}{$\mathrm{RI}^{\mathrm{b}}$} & \multirow[t]{2}{*}{$\mathrm{RI}^{\mathrm{c}}$} & Flowering & Fruit bearing & Vegetative \\
\hline & & & \multicolumn{3}{|c|}{ Relative area (\%) } \\
\hline $\bar{\beta}$-elemene & 1391 & 1391 & 0.60 & 0.50 & 1.21 \\
\hline$\alpha$-gurjunene & 1409 & 1409 & 0.15 & 0.26 & 0.24 \\
\hline$\beta$-caryophyllene & 1419 & 1418 & 3.23 & 8.97 & 6.12 \\
\hline$\beta$-gurjunene & 1428 & 1432 & 0.21 & 0.36 & 0.35 \\
\hline aromadendrene & 1438 & 1439 & 0.79 & 1.38 & 2.48 \\
\hline$\alpha$-humullene & 1453 & 1454 & 1.12 & 4.67 & 2.60 \\
\hline seychellene & 1460 & 1460 & 0.43 & 1.01 & - \\
\hline cis-muurola-4(14)-5-diene & 1462 & 1460 & 0.05 & - & 1.28 \\
\hline drima-7,9(11)-diene & 1469 & 1469 & $\operatorname{tr}$ & - & - \\
\hline$\gamma$-gurjunene & 1472 & 1473 & - & - & 0.09 \\
\hline$\gamma$-muurolene & 1476 & 1477 & 0.68 & 1.00 & 1.15 \\
\hline germacrene D & 1481 & 1480 & 2.66 & 11.82 & 5.87 \\
\hline$\beta$-selinene & 1485 & 1485 & 0.34 & 0.22 & 0.47 \\
\hline cis- $\beta$-guaiene & 1491 & 1490 & 0.21 & - & 0.23 \\
\hline bicyclogermacrene & 1496 & 1494 & 4.48 & 18.95 & 16.17 \\
\hline trans- $\beta$-guaiene & 1500 & 1500 & - & - & 0.52 \\
\hline$\alpha$-bulnesene & 1504 & 1505 & 0.14 & - & 0.18 \\
\hline germacrene $\mathrm{A}$ & 1505 & 1503 & - & 0.42 & - \\
\hline$\gamma$-cadinene & 1513 & 1513 & 0.47 & 0.60 & 0.97 \\
\hline$\delta$-cadinene & 1523 & 1524 & 1.67 & 3.63 & 2.82 \\
\hline cadina-1,4-diene & 1532 & 1532 & 0.04 & - & 0.08 \\
\hline$\alpha$-cadinene & 1537 & 1538 & 0.13 & - & 0.18 \\
\hline selina-3,7(11)-diene & 1541 & 1542 & 0.06 & - & - \\
\hline$\alpha$-calacorene & 1542 & 1542 & 0.04 & - & - \\
\hline germacrene B & 1556 & 1556 & 0.36 & 0.27 & 0.30 \\
\hline epi-longipinanol & 1559 & 1561 & - & 0.42 & - \\
\hline (E)-nerolidol & 1564 & 1564 & 1.07 & - & 0.15 \\
\hline ledol & 1566 & 1565 & - & 1.06 & - \\
\hline spathulenol & 1577 & 1576 & 2.08 & 1.62 & 7.34 \\
\hline globulol & 1584 & 1583 & 3.91 & 4.64 & 11.05 \\
\hline viridiflorol & 1591 & 1590 & - & 2.54 & - \\
\hline guaiol & 1593 & 1595 & 0.19 & 1.10 & - \\
\hline humulene epoxide II & 1608 & 1606 & 0.24 & $\operatorname{tr}$ & 1.64 \\
\hline epi-1,10-di-cubenol & 1614 & 1614 & 0.26 & $\operatorname{tr}$ & 0.29 \\
\hline epi-1-cubenol & 1627 & 1627 & 0.64 & - & 1.33 \\
\hline$\gamma$-eudesmol & 1631 & 1630 & 0.40 & 0.21 & 0.86 \\
\hline epi- $\alpha$-cadinol & 1640 & 1640 & 1.00 & 1.99 & 1.17 \\
\hline$\alpha$-muurolol & 1645 & 1645 & 0.50 & 0.56 & 0.85 \\
\hline$\alpha$-cadinol & 1654 & 1653 & 2.63 & 2.18 & 2.98 \\
\hline cadalene & 1675 & 1674 & - & - & 0.19 \\
\hline juniper camphor & 1693 & 1691 & 0.07 & - & - \\
\hline
\end{tabular}

${ }^{\mathrm{a}}$ Constituents listed in order of elution in DB-5 column. ${ }^{\mathrm{b}} \mathrm{RI}=$ Retention index calculation using a temperature program according to $\mathrm{n}$-alkanes. ${ }^{\mathrm{c}} \mathrm{RI}=$ Retention index described by Adams $17 . \operatorname{tr}=\operatorname{traces}(\%<0.01)$

compounds were mentane and pinane, best represented by limonene and $\alpha$-pinene. The principal pathway cyclization from the sesquiterpenic compounds was germacrane, represented by the main compounds bicyclogermacrene, germacrene D and globulol.

A total of 82 compounds were identified in the essential oil from the flowering stage, where there were
$48.78 \%$ of both monoterpenes and sesquiterpenes. The main compounds identified in this essential oil were limonene (22.24\%), $\alpha$-pinene (13.23\%) and $\beta$-pinene $(8.99 \%)$. During the fruit-bearing stage there were 44 compounds identified, consisting of $31.82 \%$ monoterpenes and $68.19 \%$ sesquiterpenes, the main compounds of which were bicyclogermacrene (18.95\%), germacrene 
D (11.82\%), $\beta$-caryophyllene (8.97\%), $\alpha$-pinene $(7.45 \%)$ and $\beta$-pinene $(6.69 \%)$. In the essential oil composition collected from the vegetative stage of the same plant, 60 compounds were identified. This consisted of $38.33 \%$ monoterpenes and $61.67 \%$ sesquiterpenes, with the main compounds being bicyclogermacrene (16.17\%), globulol $(11.05 \%), \beta$-caryophyllene $(6.12 \%)$ and germacrene D $(5.87 \%)$.

The chemical composition of the essential oils from different reproductive and vegetative stages was similar in relation to major components, however the composition percentage of these was very different. This is because the samples from the vegetative stage showed a higher amount of sesquiterpenes (relative area), while the flowering stage samples showed the opposite, in which the major compounds were monoterpenes.

Studies reporting on C. xanthocarpa (Limberger et al., 2004) and C. phaea (Adati, Ferro, 2006) leaves, both collected in the vegetative stage, showed predominance in the sesquiterpenes, while in the $C$. lineatifolia (Osorio et al., 2006) leaves studied during the fruit-bearing stage the major compounds were 1,8-cineol, $\alpha$-pinene and $\beta$ caryophyllene.

The production and types of the terpenes can be linked to external factors, such as differences in light, temperature and water levels (Lima et al., 2003). During the flowering stage, the plant was exposed to rain and high temperatures in the spring, while during the vegetative stage the plant was exposed to dryness and low temperatures in the fall. At the fruit-bearing stages the relative area is very well divided between monoterpenes and sesquiterpenes, with high temperatures and less rain during the summer. The chemical variability can also be related to an adaptation of pollination from different species of insects, due to the reproductive strategy of the plant (Stefanello et al., 2006).

In addition to the aforementioned factors contributing to differences in the chemical composition of the essential oils, the differing altitudes and soil types between our sample collection areas may also be a factor. Due to these factors, the $C$. adamantium leaves were collected in the cities of Dourados, Bonito, Jardim and Bela Vista during the fruit-bearing stage and were submitted to hydrodistillation where the essential oils yielded $0.39 ; 0.20 ; 0.10$ and $0.13 \%$, respectively.

Table 2 shows the difference in the chemical composition of the samples collected from different regions, while Figure 1 shows the variation in relative areas of the major compounds identified in the four cities. The samples from Dourados and Jardim are characterized by sesquiterpene bicyclogermacrene, germacrene $\mathrm{D}$ and $\beta$ - caryophyllene amounts, while the samples from Bela Vista and Bonito are similar, mainly in the monoterpene amounts of $\alpha$-pinene, $\beta$-pinene, limonene and linalool.

TABLE II - Compounds identified in the essential oil of Campomanesia adamantium leaves in different localities of Mato Grosso do Sul State, Brazil, during the fruit-bearing stage

\begin{tabular}{|c|c|c|c|c|c|c|}
\hline \multirow[t]{2}{*}{ Compounds $^{\mathrm{a}}$} & $\mathrm{IR}_{\mathrm{lit}}^{\mathrm{b}}$ & $\mathrm{IR}_{\mathrm{cal}}^{\mathrm{c}}$ & $\mathrm{BV}$ & $\mathrm{BO}$ & $\mathrm{Jd}$ & Ddos \\
\hline & \multicolumn{6}{|c|}{ Relative area (\%) } \\
\hline$\alpha$-thujene & 931 & 925 & - & $\mathrm{Tr}$ & - & $\operatorname{tr}$ \\
\hline$\alpha$-pinene & 939 & 931 & 11.29 & 12.58 & 5.02 & 7.45 \\
\hline$\alpha$-fenchene & 951 & 946 & $\mathrm{Tr}$ & 0.44 & - & - \\
\hline$n$-heptanol & 969 & 965 & - & 0.04 & - & - \\
\hline pentyl propanoate & 972 & 968 & - & $\operatorname{tr}$ & - & - \\
\hline$\beta$-pinene & 976 & 975 & 5.54 & 9.81 & 3.36 & 6.69 \\
\hline myrcene & 991 & 990 & 0.56 & 0.88 & $\operatorname{Tr}$ & - \\
\hline$\alpha$-phellandrene & 1005 & 1004 & $\operatorname{Tr}$ & 0.45 & 0.93 & - \\
\hline$\delta$-3-carene & 1011 & 1010 & $\operatorname{tr}$ & 0.22 & - & - \\
\hline$\alpha$-terpinene & 1018 & 1016 & 0.25 & 0.39 & - & - \\
\hline$o$-cymene & 1022 & 1023 & 0.41 & 0.97 & 5.45 & 0.15 \\
\hline limonene & 1031 & 1027 & 11.06 & 24.00 & $\operatorname{Tr}$ & 0.99 \\
\hline 1.8-cineole & 1033 & 1031 & 3.65 & 1.41 & - & 0.44 \\
\hline (Z)- $\beta$-ocimene & 1040 & 1037 & - & $\operatorname{tr}$ & 0.55 & - \\
\hline (E)- $\beta$-ocimene & 1050 & 1047 & 0.31 & 0.32 & 0.81 & - \\
\hline$\gamma$-terpinene & 1062 & 1058 & 0.61 & 1.25 & - & 0.14 \\
\hline terpinolene & 1088 & 1088 & 0.91 & 2.49 & 0.94 & 0.41 \\
\hline linalool & 1098 & 1100 & 7.40 & 3.60 & & 4.97 \\
\hline$\alpha$-fenchol & 1112 & 1113 & 0.30 & 0.19 & - & $\operatorname{tr}$ \\
\hline borneol & 1165 & 1164 & 0.53 & 0.39 & - & 0.24 \\
\hline terpin-4-ol & 1177 & 1176 & - & 0.53 & - & 0.26 \\
\hline
\end{tabular}


TABLE II - Compounds identified in the essential oil of Campomanesia adamantium leaves in different localities of Mato Grosso do Sul State, Brazil, during the fruit-bearing stage (cont.)

\begin{tabular}{|c|c|c|c|c|c|c|}
\hline \multirow[t]{2}{*}{ Compounds $^{\mathrm{a}}$} & $\mathrm{IR}_{\text {lit }}^{\mathrm{b}}$ & $\mathrm{IR}_{\mathrm{cal}}{ }^{\mathrm{c}}$ & $\mathrm{BV}$ & $\mathrm{BO}$ & $\mathrm{Jd}$ & Ddos \\
\hline & \multicolumn{6}{|c|}{ Relative area (\%) } \\
\hline$\alpha$-terpineol & 1189 & 1189 & 2.38 & 0.17 & - & 0.58 \\
\hline Myrtenol & 1194 & 1195 & - & $\operatorname{tr}$ & - & - \\
\hline (E)-2-decenal & 1261 & 1261 & - & $\operatorname{tr}$ & - & - \\
\hline perilla aldehyde & 1271 & 1273 & - & $\operatorname{tr}$ & - & - \\
\hline perillol & 1295 & 1297 & 1.24 & $\operatorname{tr}$ & - & - \\
\hline$\delta$-elemene & 1339 & 1337 & 0.31 & 0.37 & $\operatorname{Tr}$ & 0.29 \\
\hline$\alpha$-cubebene & 1351 & 1350 & - & $\operatorname{tr}$ & - & - \\
\hline$\alpha$-ilangene & 1372 & 1372 & - & - & - & 0.17 \\
\hline$\alpha$-copaene & 1376 & 1376 & 0.20 & 0.27 & 1.42 & 1.57 \\
\hline$\beta$-elemene & 1391 & 1392 & 0.81 & 0.27 & 0.93 & 0.50 \\
\hline$\alpha$-gurjunene & 1409 & 1409 & 0.41 & $\operatorname{tr}$ & - & 0.26 \\
\hline$\beta$-caryophyllene & 1418 & 1419 & 3.12 & 3.15 & 8.14 & 8.97 \\
\hline$\beta$-gurjunene & 1432 & 1429 & - & 0.13 & $\operatorname{Tr}$ & 0.36 \\
\hline aromadendrene & 1439 & 1439 & 1.32 & 0.54 & 0.50 & 1.38 \\
\hline Z- $\beta$-farnesene & & 1443 & - & 0.04 & - & - \\
\hline$\alpha$ - caryophyllene & 1454 & 1453 & 1.01 & 0.93 & 2.07 & 4.67 \\
\hline Seichellene & 1460 & 1460 & 0.55 & 0.30 & 0.70 & 1.01 \\
\hline$\gamma$-muurolene & 1477 & 1477 & 0.76 & 0.57 & 1.64 & 1.00 \\
\hline germacreno D & 1480 & 1481 & 4.86 & 2.97 & 10.65 & 11.82 \\
\hline$\beta$-selinene & 1485 & 1486 & - & 0.17 & 0.77 & 0.22 \\
\hline valencene & 1491 & 1491 & - & 0.24 & 0.81 & - \\
\hline biciclogermacrene & 1494 & 1496 & 9.13 & 5.97 & 20.05 & 18.95 \\
\hline$\alpha$-bulnesene & 1505 & 1505 & 0.31 & - & - & - \\
\hline germacrene A & 1503 & 1505 & - & 0.15 & - & 0.42 \\
\hline$\gamma$-cadinene & 1513 & 1514 & 0.49 & 0.39 & 0.82 & 0.60 \\
\hline$\delta$-cadinene & 1524 & 1524 & 1.25 & 1.25 & 4.18 & 3.63 \\
\hline cadina-1,4-diene & 1532 & 1532 & - & $\operatorname{tr}$ & - & - \\
\hline$\alpha$-cadinene & 1538 & 1538 & - & $\operatorname{tr}$ & - & - \\
\hline selina-3,7(11)-diene & 1542 & 1542 & - & $\operatorname{tr}$ & - & - \\
\hline elemol & 1549 & 1552 & - & $\operatorname{tr}$ & - & - \\
\hline germacrene B & 1556 & 1557 & - & 0.16 & 0.64 & 0.27 \\
\hline epi-longipinanol & 1561 & 1560 & - & 0.12 & - & 0.42 \\
\hline (E)-nerolidol & 1564 & 1564 & 5.50 & 0.82 & $\operatorname{Tr}$ & - \\
\hline ledol & 1565 & 1565 & - & 0.13 & 1.93 & 1.06 \\
\hline spathulenol & 1576 & 1576 & 2.64 & 1.15 & 1.15 & 1.62 \\
\hline globulol & 1583 & 1583 & 6.46 & 3.63 & 5.82 & 4.64 \\
\hline viridiflorol & 1590 & 1590 & 1.85 & 1.16 & 2.38 & 2.54 \\
\hline cis- $\beta$-elemonene & 1594 & 1593 & - & - & 1.18 & \\
\hline guaiol & 1595 & 1595 & - & 0.70 & - & 1.10 \\
\hline humullene epoxide II & 1606 & 1609 & 0.33 & 0.19 & $\operatorname{Tr}$ & $\operatorname{tr}$ \\
\hline epi-1,10-di-cubenol & 1614 & 1615 & - & 0.18 & $\operatorname{Tr}$ & $\operatorname{tr}$ \\
\hline epi-10- $\delta$-eudesmol & 1619 & 1619 & - & 0.23 & $\operatorname{Tr}$ & - \\
\hline epi-1-cubenol & 1627 & 1627 & 0.44 & 0.56 & 0.40 & - \\
\hline$\gamma$-eudesmol & 1630 & 1630 & - & $\operatorname{tr}$ & 0.25 & 0.21 \\
\hline epi- $\alpha$-cadinol & 1641 & 1641 & 1.70 & 1.92 & - & 1.99 \\
\hline$\alpha$-muurolol & 1645 & 1646 & 0.36 & 0.23 & 3.00 & 0.56 \\
\hline$\alpha$-cadinol & 1653 & 1654 & 1.89 & 2.35 & 0.84 & 2.18 \\
\hline
\end{tabular}

${ }^{a}$ Constituents listed in order of elution in DB-5 column. ${ }^{b} \mathrm{RI}=$ Retention index calculation using a temperature program according to $\mathrm{n}$-alkanes. ${ }^{\mathrm{c}} \mathrm{RI}=$ Retention index described by Adams17. $\operatorname{tr}=\operatorname{traces}(\%<0.01)$.

From these results it can be concluded that the chemi- adamantium is influenced during different stages (including cal composition of the essential oil from the leaves of the $C$. the fruit-bearing stage) as well as by different regions. 


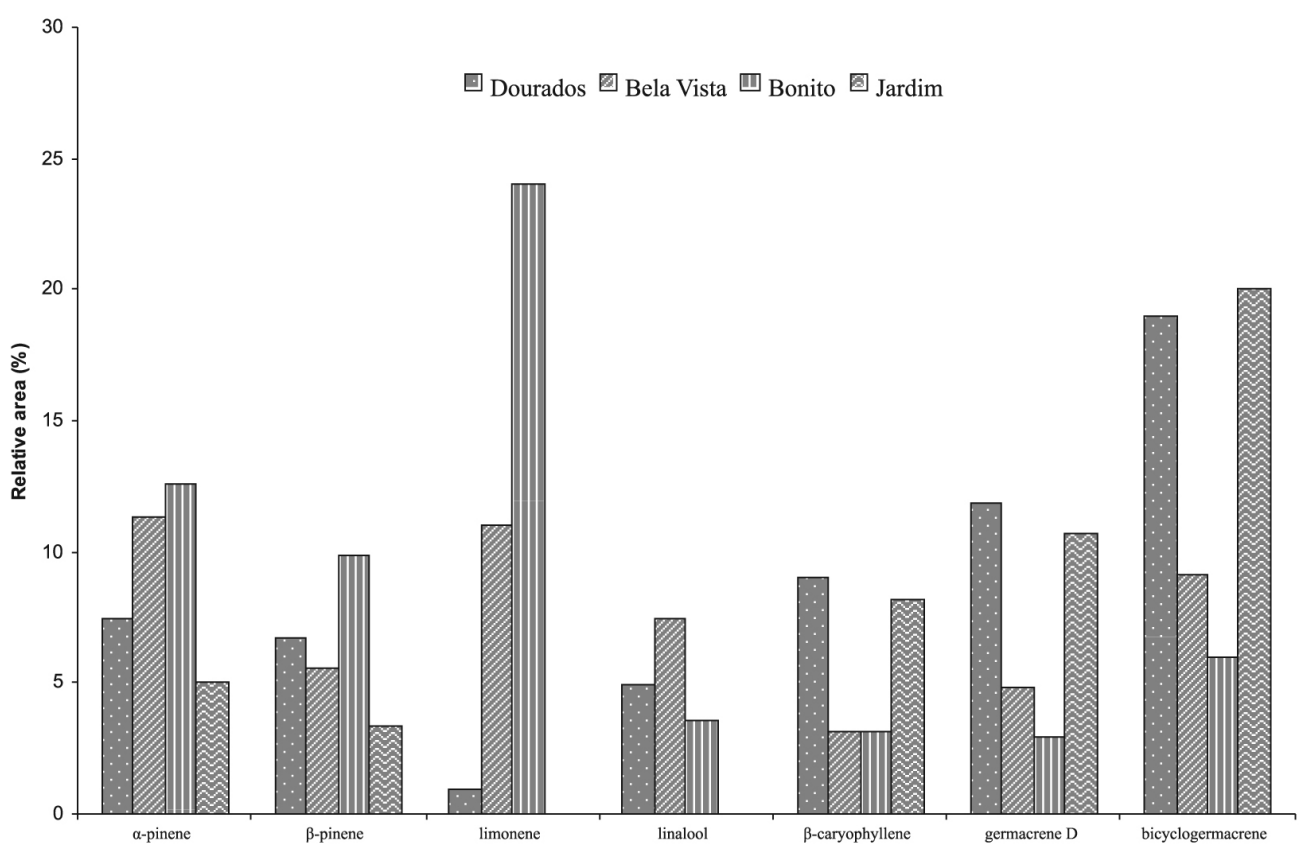

FIGURE 1 - Major compounds identified in the Campomanesia adamantium leaves collected in different localities of Mato Grosso of the Sul State, Brazil during the fruit-bearing stage.

\section{Determination of DPPH Radical-Scavengers}

The essential oils were screened for antioxidant activity. The use of 1,1-diphenyl-2-picryl-hydrazyl (DPPH) as a reagent for screening the antioxidant activity of small molecules has been reported (Tepe et al., 2005).

The inhibition percentage of the radical-scavengers activity in the essential oil was $9.91 \%\left(2270 \mu \mathrm{g} \cdot \mathrm{mL}^{-1}\right)$ at the flowering stage, $7.47 \%\left(2390 \mu \mathrm{g} . \mathrm{mL}^{-1}\right)$ at the fruit-bearing stage, and $6.89 \%\left(2320 \mu \mathrm{g} \cdot \mathrm{mL}^{-1}\right)$ at the vegetative stage. The reference compound quercetin showed a scavenging effect of $90 \%\left(20 \mu \mathrm{g} \cdot \mathrm{mL}^{-1}\right), 91 \%\left(40 \mu \mathrm{g} \cdot \mathrm{mL}^{-1}\right), 93 \%(80$ $\left.\mu \mathrm{g} \cdot \mathrm{mL}^{-1}\right), 94 \%\left(160 \mu \mathrm{g} \cdot \mathrm{mL}^{-1}\right)$ and $97 \%\left(320 \mu \mathrm{g} \cdot \mathrm{mL}^{-1}\right)$.

In this test, the scavenging of the DPPH radical is followed by monitoring of the decrease in absorbance at $517 \mathrm{~nm}$, which occurs due to the antioxidant reduction, and has been used to assess the ability of phenolic compounds to transfer labile $\mathrm{H}$ atoms to radicals (Djeridane et al.,
2006). The lower antioxidant activity has been attributed to the absence and/or lower amount of the donor groups of the electron in ortho position in relation to phenolic hydroxyl, and the presence of larger amounts of hydrocarbons terpenes. This result is in agreement with other studies of essential oils with similar patterns (Sacchetti et al., 2005).

\section{Assay of antimicrobial activity}

Results from the assessment of antimicrobial activity using the Agar diffusion disc method are summarized in Table 3. The essential oil at all stages exhibited moderate to high activity against the tested microorganism. The essential oil in the flowering and fruit-bearing stages exhibited an even better effect than that provided by the reference antibiotics against Staphylococcus aureus and Candida albicans, and moderate effect in relation to Pseudomonas aeruginosa and Escherichia coli. Meanwhile, the samples

TABLE III - Antimicrobial activity of the essential oil from Campomanesia adamantium leaves

\begin{tabular}{lcccc}
\hline Microorganism & EOFl $^{*}$ & EOFr* $^{*}$ & EOV $^{*}$ & Antibiotics \\
\hline Staphylococcus aureus & $20.00 \pm 0.40$ & $20.00 \pm 0.60$ & $16.00 \pm 0.20$ & $22.00 \pm 0,60^{\mathrm{a}}$ \\
Pseudomonas aeruginosa & $10.00 \pm 0,20$ & $10.00 \pm 0,00$ & $6.00 \pm 0,00$ & $17.40 \pm 0.60^{\mathrm{b}}$ \\
Escherichia coli & $2.00 \pm 0,00$ & $2.00 \pm 0,00$ & $2.00 \pm 0,00$ & $4.00 \pm 0.00^{\mathrm{c}}$ \\
Candida albicans & $26.00 \pm 0,60$ & $26.00 \pm 0,40$ & $16.00 \pm 0.20$ & $22.00 \pm 0.40^{\mathrm{d}}$ \\
\hline
\end{tabular}

*EOFl: essential oil flowering stage; EOFr: essential oil fruit-bearing stage; EOV: essential oil vegetative stage. All analyses used $40 \mu \mathrm{g}$ of the essential oil samples. ${ }^{\mathrm{a}}$ nitrofurantoin $(300 \mu \mathrm{g}) ;{ }^{\mathrm{b}}$ Impenen $(10 \mu \mathrm{g}) ;{ }^{\mathrm{c}}$ tetracicilin $(30 \mu \mathrm{g})$; ${ }^{\mathrm{d}}$ fluconazole $(50 \mu \mathrm{g})$. 
of essential oil during the vegetative stage showed very weak activity against all tested microorganisms.

The different antimicrobial activity offered by essential oils, can be linked to their different chemical compositions, therefore the essential oils isolated from the flowering and fruit-bearing stages have larger amounts of monoterpene hydrocarbons with allylic groups and ether, alcohol, aldehydes, ketones, esters and phenols than the essential oil isolated from the vegetative stage. The biological activity of the terpenes can be seen in relation to the chemical structure, functional groups and stereochemistry of identified compounds (Henriques et al., 2006).

\section{ACKNOWLEDGEMENT}

The authors thank FUNDECT, CNPq and CAPES for financial support and grants, respectively, and Dr. Marcos Sobral for identifying the botanical material.

\section{REFERENCES}

ADAMS, R. P. Identification of essential oil components by gas chromatography/mass spectroscopy. Illinois: Allured Publishing Corporation, 1995. p.1-69.

ADATI, R. T.; FERRO, V. O. Volatile oil constituents of Campomanesia phaea (O. Berg) Landrum. (Myrtaceae). J. Essent. Oil Res., v.18, p.691-692, 2006.

BONILLA, A.; DUQUE, C.; GARZON, C.; TAKAISHI, Y.; YAMAGUCHI, K.; HARA, N.; FUJIMOTO, Y. Champanones, yellow pigments from the seeds of champa (Campomanesia lineatifolia). Phytochemistry, v.66, p.1736$1740,2005$.

BRASILEIRO, B. G.; PIZZIOLO, V. R.; RASLAN D. S.; JAMAL C. M.; SILVEIRA D. Antimicrobial and cytotoxic activities screening of some Brazilian medicinal plants used in Governador Valadares district. Rev. Bras. Ciênc. Farm., v.42, p.195-202, 2006.

DJERIDANE, A.; YOUSFI, M.; NADJEMI, B.; BOUTASSOUNA, D.; STOCKER, P.; VIDAL, N. Antioxidant activity of some algerian medicinal plants extracts containing phenolic compounds. Food Chem., v.97, p.654-660, 2006.

HENRIQUES, A. T.; SIMÕES-PIRES, C. A.; APEL, M. A. Química de produtos naturais, novos fármacos e a moderna farmacognosia. Itajaí: Univali, 2006. p.1-303.
HUDAIB, M.; SPERONI, E.; PIETRA, A. M. D.; CAVRINI, V. GC/MS evaluation of thyme (Thymus vulgaris L.) oil composition and variations during the vegetative cycle. $J$. Pharm. Biomed. Anal., v.29, p.691-700, 2002.

ISIDOROV, V. A.; ZENKEVICH, I. G.; DUBIS, E. N.; SLOWIKOWSKI, A.; WOJCIUK, E. Group identification of essential oils components using partition coefficients in a hexane-acetonitrile system. J. Chromatogr. A, v.814, p.253-260, 1998.

LIMA, H. R. P.; KAPLAN, M. A. C.; CRUZ, A. V. M. Influência dos fatores abióticos na produção e variabilidade de terpenóides em plantas. Floresta Ambiente, v.10, p.71-77, 2003.

LIMBERGER, R. P.; APEL, M. A.; SOBRAL, M.; MORENO, P. R. H.; HENRIQUES, A. T.; MENUT, C. Aromatic plant from Brazil: chemical composition of essential oils from some Campomanesia species (Myrtaceae). J. Essent. Oil Res., v.13, p.113-115, 2001.

LIMBERGER, R. P.; SOBRAL, M.; HENRIQUES, A. T.; MENUT, C.; BESSIÈRE J. -M. Óleos voláteis de espécies de Myrcia nativas do Rio Grande do Sul. Quim. Nova, v.27, p.916-919, 2004.

LORENZI, H.; BACHER, L.; LACERDA, M.; SARTORI, S. Frutas brasileiras exóticas cultivadas: de consumo in natura. Nova Odessa: Instituto Plantarum, 2006. p.1-640.

OSORIO, C.; ALARCON, M.; MORENO, C.; BONILLA, A.; BARRIOS, J.; GARZON, C.; DUQUE, C. J. Characterization of odor-active volatiles in Champa (Campomanesia lineatifolia R. \& P.). J. Agric. Food Chem., v.54, p.509-516, 2006.

RAMALHO, V. C.; JORGE, N. Antioxidantes utilizados em óleos, gorduras e alimentos gordurosos. Quim. Nova, v.29, p.755-760, 2006.

RAHALISON, L.; HAMBURGER, M.; MONOD, M.; FRENK, E.; HOSTETTMANN, K. Anti-fungal tests in phytochemical infestigations: comparison of bioautographic methods using phytopathogenic and human pathogenic fungi. Planta Med., v.60, p.41-44, 1994.

SACCHETTI, G.; MAIETTI, S.; MUZZOLI, M.; SCAGLIANTI, M.; MANFREDINI, S.; RADICE, M.; BRUNI, R. Comparative evaluation of 11 essential oils of different origin as functional antioxidants, antiradicals and antimicrobials in foods. Food Chem., v.91, p.621-632, 2005. 
SALEHI, P.; SONBOLI, A.; EBRAHIMI, S. N.; YOUSEFZADI, M. Antibacterial and antioxidant activities of the essential oils and various extracts of Salvia sahendica in different phenological stages. Chem. Nat. Compd., v.43, p.328-330, 2007.

SCHMEDA-HIRSCHMANN, G. Flavonoids from Calycorectes, Campomanesia, Eugenia and Hexachlamys species. Fitoterapia, v.66, p.373-374, 1995.

STEFANELLO, M. E. A.; CERVI, A. C.; WISNIEWSKI JR., A.; SIMIONATTO, E. L. Óleo essencial de Gochnatia polymorpha (LESS) CABR. Ssp floccosa Cabr. Quim. Nova, v.29, p.999-1002, 2006.

TEPE, B.; SOKMEN, M.; SOKMEN, A.; DAFERERA, D.; POLISSIOU, M. Antimicrobial and antioxidante activity of the essential oil and various extracts of Cyclotrichium origanifolium (Labill.) Manden. \& Scheng. J. Food Eng., v.69, p.335-342, 2005.
VALLILO, M. I.; LAMARDO, L. C. A.; GABERLOTTI, M. L.; OLIVEIRA, E.; MORENO, P. R. H. Composição química dos frutos de Campomanesia adamantium (Cambessédes) O. Berg. Ciênc. Tecnol. Aliment., v.26, p.805-810, 2006.

ZHAO, C. X.; LIANG, Y. Z.; FANG, H. Z.; LI, X. N., Temperature-programmed retention índices for a gás chromatography-mass spectroscopy analysis of plant essential oils. J. Chromatogr. A., v.76, p.1096-1100, 2005.

Received for publication on $02^{\text {nd }}$ October 2008 . Accepted for publication on $25^{\text {th }}$ June 2009. 